\title{
Alfonso Lopez Trujillo, Familia, vida y evangelizacion, Editorial Verbo Divino, Estella (Navarra) 2000, ss. XXIV + 604
}

Życie społeczne ludzi przybiera bardzo zróżnicowane formy, które niejednokrotnie uwarunkowane były wielorakimi i zróżnicowanymi czynnikami. Obejmują one mniejsze, czy większe ich zbiorowości, wspólnoty, czy inne bardzo różniące się struktury zbiorowe. Także w sensie geograficznym obejmują zróżnicowane terytoria, a i czasowo wpisane są w przemijanie typowe dla zjawisk znaczonych czasem. Bogactwo to jest jednak jednym ze szczególnie ważnych walorów kulturowych i cywilizacyjnych, choć czasem przybierało znacznie różniące się formy, czy przejawy. Oczywiście, także mają one swe odniesienia do sfery ekonomicznej, a nawet politycznej.

Jednak w całym tym bogactwie szczególne miejsce zajmuje rodzina, trwała wspólnota mężczyzny i kobiety, otwarta na niepowtarzalny dar życia, rozeznawany twórczo i osobowo przez człowieka, sprawdzona twórczo na przestrzeni dziejów i to w wielorakich oraz zróżnicowanych kulturach. Zatem rodzina pozostaje na zawsze niepowtarzalnym fenomenem naturalnym, który wpisuje się także w.sferę kulturową, czy etyczno-moralną, choć może czasem nie jest to w pełni twórczo uświadamiane. Przecież jest ona niepowtarzalnym wyrazem wspólnotowej natury człowieka, w bogactwie płci, miłości i daru życia. Jako jedyna tworzy „communio personarum”. Pozostaje zatem ciągle niezwykłym przedmiotem interdyscyplinarnych badań.

Całość książi otwiera dość obszerny spis treści, który ze względu na szczegółowy podział jest dobrym wprowadzeniem $\mathrm{w}$ prezentowane treści (s. V-XII). Z kolei zamieszczono wprowadzenie pióra samego autora (s. XIII-XX) oraz wykaz skrótów (s. XXI-XXIII). Następnie zamieszczono 45 szczegółowych tekstów, określonych tytułem, datą oraz miejscem wygłoszenia.

Dla choćby schematycznego wskazania na treść warto podać tytuły poszczególnych wystąpień: „Nowa ewangelizacja, rodzina i sekty” (s. 1-14); „Rodzina: od celebracji do świadectwa” (s. 15-39); „Od desperacji do nadziei: o ekologię ludzką" (s. 40-50); „Magisterium katolickie w obronie prawdy i życia” (s. 51-67); „Misja polityków i legislatorów dzisiaj: specyfika etyczna” (s. 68-78); 
„Inauguracja Roku Rodziny” (s. 79-83); „Prezentacja Listu Ojca św. Jana Pawła II do rodzin" (s. 84-90).

A oto tytuły dalszych tekstów: „Wartości niezbywalne w Liście Stolicy Apostolskiej. O prawach rodziny” (s. 91-100); „Kobieta, małżonka i matka” (s. 101-118); „Międzynarodowy Rok Rodziny” (s. 119-138); „Rodzina, sercem cywilizacji miłości” (s. 139-154); „Słowa powitania Jana Pawła II” (s. 155-156); „Papież rodziny” (s. 157-159); „Wystąpienie podczas XLI sesji generalnej ONZ” (s. 160-164).

Dalsze teksty: „Znać, kochać, służyć życiu ze strony rodziny” (s. 165-174); „Prawda rodziny” (s. 175-189); „Zakończenie Roku Rodziny” (s. 190-196); „Homilia w Kanie Galilejskiej” (s. 197-199); „Linie fundamentalne w Encyklice "Evangelium vitae»" (s. 200-210); „Przekazywanie wiary w rodzinie” (s. 211 -226); „Napięcie między kulturą życia i kulturą śmierci w "Evangelium vitae»" (s. 227-245); „Ekonomia i rodzina, odczucia z pewnego spotkania” (s. 246252).

Z kolei zamieszczono teksty: „Fundament antropologiczny w encyklice „Evangelium vitae«” (s. 253-268); „Walka przeciw wykorzystywaniu seksualnemu dzieci: wyzwanie wobec roztropności i ludzkości ludów” (s. 269-276); „Za autentycznym wychowaniem seksualnym” (s. 277-298); „Refleksje wokół kwestii demograficznej” (s. 299-310); „Narzeczeństwo i miłość weselna w »Pieśni nad pieśniami «" (s. 311-324); „Rodzina: dar i ugoda, nadzieja ludzkości” (s. 325-377); „Wyzwania rodziny i jej nadzieje w encyklice »Evangelium vitae»" (s. 378$-387)$.

Następne tytuły: „Kościół i obrona instytucji rodzinnych” (s. 388-401); "Społeczeństwo z chorym sercem” (s. 402-403); „Pozdrowienie Ojca Świętego” (s. 404-406); „Spowiednicy: ministrowie pojednania w prawdzie i miłosierdziu” (s. 407-422); „Fundamenty antropologiczne kultury życia” (s. 423-446); „Młodzież i rodzina” (s. 447-461); „Duch, Pan i Dawca życia: rodzina i życie oblicze Trzeciego Milenium” (s. 462-473); „Trzydzieści lat od Konferencji w Medellin" (s. 474-498).

Pozostałe wystąpienia: „Oczekiwania duszpasterskie w trzydzieści lat po encyklice »Humanae vitae»” (s. 499-508); „Pozdrowienie Ojca świętego podczas II Międzynarodowego Kongresu Teologiczno-duszpasterskiego w Rio" (s. 509-511); „Młodzież i rodzina, priorytetem w Kościele” (s. 512-524); „Orędzie chrześcijańskie na temat życia” (s. 525-542); „Ojcostwo Boże i ojcostwo w rodzinie” (s. 543-581); „Starsi i rodzina” (s. 582-589); „Kościół, rodzina kapłana. Rodzina, kołyska kapłana” (s. 590-592); „Jezus Chrystus, Człowiek drugiego Tysiąclecia" (s. 593-604). 
Dzieło to zawiera liczne i bardzo zróżnicowane teksty kardynała A. L. Trujillo, związane z problematyką rodziny i życia. Zawiera teksty od 15 marca 1991 do grudnia 1999 r., a więc z lat jego owocnej pracy w Stolicy Apostolskiej. Są to bardzo zróżnicowane, zarówno pod względem treści, jak i formy, teksty koncentrujące się jednak wokół zagadnień rodziny i życia, wpisanych w dzieła nowej ewangelizacji. Głoszone one były m.in. w Rio de Janeiro, Nazaret, Lima, Santiago de Chile, Toronto, Bogota, ale znaczna większość w Rzymie lub Watykanie. Także bardzo zróżnicowani byli ich adresaci.

Autor jest z pochodzenia Kolumbijczykiem i do momentu rozpoczęcia pracy w Watykanie był znaczącą postacią w Kościele latynoamerykańskim. Zwłaszcza jego zaangażowanie $\mathrm{w}$ ramach CELAM było cennym wkładem $\mathrm{w}$ wielość procesów ewangelizacyjnych, jakie przeżywała wówczas Ameryka Łacińska. Kard. A. Lopez Trujillo od 1990 r. jest przewodniczącym Papieskiej Rady ds. Rodziny, niezwykle aktywnym i dynamicznym w trosce o problematykę rodziny oraz życia. Ma w swym dorobku liczne publikacje książkowe, m.in.: Testimonios (Plaza y Janes 1997), La familia: don y compromiso, esperanza de la humanidad (Citta Nuova 1997), Caminos de evangelizacion (BAC 1985). Uczestniczył $\mathrm{w}$ wielu spotkaniach, zjazdach i sympozjach, wygłaszając liczne referaty, których znaczna część znajduje się w prezentowanej książce.

Interesujący nas zbiór artykułów ma dwa podstawowe wymiary, które są komplementarne. Pierwszy z nich to wyraźnie duszpasterski, a drugi socjopolityczny. To dość syntetyczne i schematyczne określenie. Wydaje się jednak, że dopiero twórcze spotkanie ich obu daje pełniejszy obraz, a tym samym bardziej wiarygodny w zakresie omawianej problematyki rodziny.

Książka ta jest także odzwierciedleniem wielu dyskusji, a niekiedy wręcz walki na rzecz rodziny i życia. Jest to historyczne świadectwo choćby Konferencji w Kairze, czy wystąpienia kardynała z okazji Międzynarodowego Roku Rodziny oraz w imieniu Ojca św. podczas obrad ONZ-u. Przy każdej takiej okazji wybrzmiewa wielkie oddanie oraz miłość i troska o sprawy rodziny A. L. Trujillo, który wręcz stał się pasjonatem w walce o rodzinę i należne jej miejsce we współczesnym świecie. W pewnym sensie omawiana publikacja jest także wynikiem prac prowadzonych w kierowanej przez kardynała Papieskiej Radzie ds. Rodziny. 